\title{
Psychosocial Factors that Contribute to Underachievement among Pupils in Rural Areas of Fako Division
}

\author{
Zora Ikala Ekonde \\ B.Ed (Hons) CST, M.Ed (Hons) EPY, PhD in View \\ Faculty of Education, University of Buea, Cameroon, Central Africa
}

\begin{abstract}
This study examined, Psychosocial Factors that Contribute to Underachievement among Primary School Pupils in the Rural Areas of Fako Division in the South West Region, Republic of Cameroon. The survey research design was used. The sample consisted of 150 pupils, 28 teachers and 50 parents. The table of random numbers was used to select pupils, the purposive sampling technique was used to select parents and all the teachers of the sampled schools were used for this study. Instruments for data collection were two sets of questionnaires, one for teachers and another for pupils; interview guide for pupils. One was formulated to guide the study.
\end{abstract}

The finding showed that there is a high relationship between pupils' self perception and their underachievement in rural areas and at the end, recommendations were made.

Keywords: Psychosocial, Underachievement, Rural Areas

\section{INTRODUCTION}

Education is a vital instrument for the socio-economic and cultural development of any given society. In this respect every nation or community is striving to provide quality basic education to its citizens. To do this, a lot of resources are set aside for education. For example, the 2010 budget of the Cameroon Ministry of Basic Education is one of the highest. In the past the objective of elementary (basic) education was to teach the 3Rs (Writing, Reading Arithmetic).Over the years the objectives of elementary or primary education have been extended to include other disciplines such as Sport and Physical Education, Information and Communication Technology |(ICT), Environmental Education, HIV/AIDS, and so on.

The importance of education in rural communities was recognized by the Cameroon government. That is why in 1967 and 1973 two Curriculum Research Institutes called IPAR (Institute Pédagoque à la Vocation Rurale) were created in Yaounde and Buea, respectively. They were given the mission to adapt school programmes to rural environment and local needs. Cameroon educational system was facing many problems and to this effect in 1995 a National Forum on Education was held in Yaoundé to seek solutions to these problems. An important outcome of the deliberation of the National Forum was the Issue of Law No. 98/004 of $14^{\text {th }}$ April 1998 which laid down guidelines for education in Cameroon. This law defines the purpose of school as follows: "Guarantees the physical, intellectual, civic, moral and personality development of the child." Furthermore, according to the National Syllabuses for English-Speaking Primary Schools (MINEDUC, 2000), the aims of basic education are to equip pupils with basic societal, functional skills and national integration as well as master course content for certification (for example the First School Leaving Certificate Examination abbreviated FSLC) and selection (for example the Common Entrance Examinations).
Children are educated through the teaching-learning process. On the other hand it is through evaluation in the form of examinations that stakeholders can judge the quality of education offered to citizens and the performance of learners. Several factors influence the effectiveness of the teaching-learning process and consequently learners' performance. These factors may include psychological characteristics of learners, socio-cultural factors as well as material, financial and human resources. The psychological characteristics of learners include age, interest, locus of control, self-esteem, and so on. The socio-cultural characteristics include beliefs and social relationships. The environmental factors involved the school and home environment. Material, financial and human resources concern the availability of school infrastructure (classrooms furniture and playgrounds) and the quantity and quality of teachers.

\section{STATEMENT OF THE PROBLEM}

Children's academic achievement is a central issue in our school systems. It has been observed that even in the same class, there are some children who are high achievers while some are underachievers. The same situation is found in different schools where some schools are always performing well while others constantly perform poorly. School location that is either in urban or rural setting have also shown differences in performance.

A child's psychological, cultural and environmental factors seem to contribute greatly to these differences in achievement. The way a child is brought up will build up an image in the way people see him/her or how he/she sees himself/herself. This image may be positive or negative and reflects on the self perception of that individual. It is likely that this situation contributes greatly to achievement of pupils in primary schools in our rural communities. Cultural practices influence a child's beliefs. These beliefs seem to be a cover which determines children's desire to attend school, be serious in class work and work hard to succeed. This too 
may be a contributive factor on the achievement of pupils in rural areas. Environmental factors may either play for or against achievement in schools. They may groom up children to be interested in activities which deviate the child's attention from school and achievement will be affected.

Analysis of the results of the First School Leaving Certificate Examination (FSLC) centres in urban and rural areas in Fako Division shows a great difference in their performance, of schools in rural areas and those in urban areas. It is likely that these psychosocial factors play a great role in determining a child's academic achievement. To what extent then do the prevailing psychosocial factors contribute to this underachievement among primary school pupils' in the rural communities? This is the main concern of this study.

\section{Research Objective}

To find out if the self perception of pupils in rural primary schools affect their performance

\section{Research Question}

To what extent does the self perception of pupils in rural areas influence their level of underachievement in school?

\section{BACKGROUND}

Cameroon Constitution of 1996 stipulates compulsory primary education. To this effect the Government of Cameroon has created primary schools all over the country even in remote areas in order to provide education and promote balanced development. Communities in Cameroon are subdivided into urban and rural communities. The urban communities are characterized by the availability of amenities such as pipe born water supply, good roads, and health facilities. A large number of people are found in urban communities. Most of the towns and cities make up the urban communities. On the other hand rural communities are characterized by lack of basic amenities such as health facilities, good roads, pipe-born water and electricity supply. Communication facilities such as radio and television signals are not readily available in most rural communities. Generally the standard of living in rural communities is low. The villages make up the rural communities.

An observation of schools in rural areas reveals that most of them lack infrastructure, furniture, and didactic materials. There is lack of well equipped libraries in schools. The 2009 Statistical Yearbook of the Regional Delegation of Basic Education for the South West shows a very high pupil teacher ratio for the majority of rural schools. There are many class six schools with three teachers. This high pupilteacher ratio does not permit the best teacher-pupil relationship to prevail.

Parents of pupils in rural areas are mostly peasant farmers, hunters or fishermen. A significant number of these parents are illiterate or have low educational background. Due to parents' illiteracy and other socio-cultural factors, parents of pupils in rural areas give little importance to the education of their children. Most of them fail to provide their children basic school needs, and to follow up their children's learning at school and at home. During periods such as farming, hunting and fishing, they ask their children to absent from school and accompany them to carry out these activities. Classrooms in Mboko in Limbe III Subdivision are scanty during fishing periods where pupils are involved in fishing. Also, in most rural areas many children are absent from school on market days. In the same vein, pupils' indiscipline is very high during market days wherein pupils of schools located near the markets escape from classrooms to the market.

Some children in rural areas are less interested in attending school. Their teachers even beg them to be serious in school. Their homework is either not done or completed in time. Some of these rural children behave as though if they are serious with their studies the prime beneficiary will be their teachers. From this attitude one can infer that they attribute their success or failure to external factors (teachers and parent). As concerns self esteem and confidence, some of these rural school pupils lack self confidence and self-esteem with challenging academic topics. During Regional or National School competitions, for example during the "Federation Nationale de Sport Scolaire" (FENASSCO), pupils of rural schools show low self-esteem towards disciplines such as volley ball and basket ball. Topics such as AIDS/HIV and ICT are discussed with less confidence by pupils of rural areas.

Comparing the FSLC and Common Entrance percentage pass of pupils of examination centres located in urban areas to those in rural areas, there exists a big gap. For example the 2008 FSLC result booklet for the South West Region shows the performance of the following schools.

\section{Table 1: Statistical Representation of the Results of some selected}

Schools in Rural and Urban Areas of Fako Division at the First School Leaving Certificate Examination in the 2008/2009 session

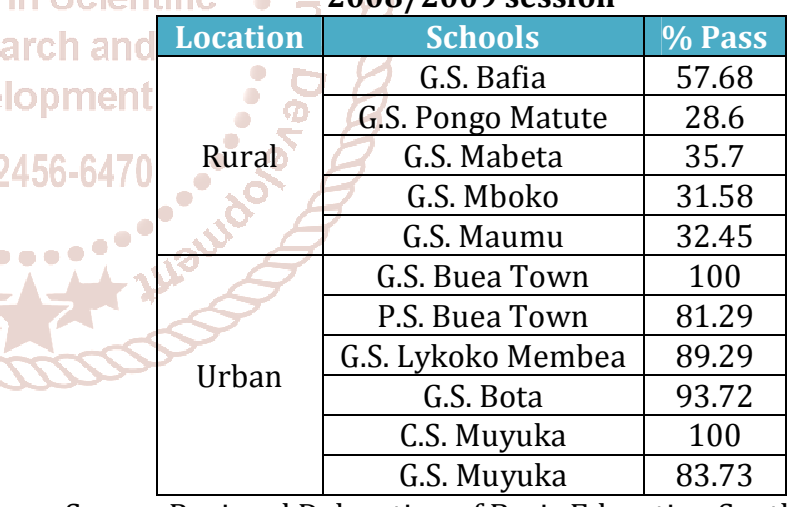

Source:Regional Delegation of Basic Education South West

These results and statistics reveal that there is a problem of underachievement among primary school pupils in rural areas. The prevailing cultural, socio-economic and psychological factors described above can contribute to this underachievement.

There are some psychological theories that can explain the relationship between psychological factors and underachievement. These theories include Albert Bandura's Self-Efficacy Theory, Bronfenbrenner's Socio-cultural theory, Weiner's Attribution theory and Moos's theory of social climate.

In this study, self perception refers to the way a primary school pupil in the rural area sees himself, either as an achiever or as an underachiever. To better understand this concept, the researcher looked into some related concepts like the learner's self concept and self esteem. 


\section{Self-concept}

Many researchers have found positive correlation between self-concept and academic achievements thus the need for educators to enhance self-concept to raise students' and pupils' academic achievements (Crist, Hoge, Smith, 1995). However, a review of several studies further showed that academic self-concept is substantially related to academic underachievement but almost unrelated to global selfconcept or non-academic components of self-concept (Marsh, 1993). If self-concept is so important to a pupil's underachievement, it may be vital to examine what it is and how it can be maintained or built up in the learner to enhance learning. The self is a presentation of the ego, which is a combination of all that the self executes such as awareness, evaluation, regards and control of the being (Patterson, 1966).

Concept is a mental representation of all one's experiences of the world that allows one to classify objects (Rosenthal and Jacobson in Hocks, 1992). Self-concept may be the substantive and evaluative core of oneself particularly as we think it appears to others and in relation to the world around us (Nicky Hayes, 1984). This self-concept is not stable but develops over time and therefore can be either improved or watered down.

Argyle, (1969) identifies four main factors that affect the self-concept of an individual and they are: other people's reactions; comparisons which we make with other people; the roles we play in life and the identifications which we make. The first factor deals with those we think are our significant others like our parents, teachers and friends, whose opinions about us count. Hayes (1984) says these groups of persons should be those who consider us experts in the fields in which we wish to strive towards. In a school milieu, such will be the teachers of the various school subjects.

The next factor comes in because the people we compare ourselves with would be like us in some aspects or a bit more than us in what we aspire for. This group is what psychologists call a reference group. This group may be our peer group or whom ever we socialize with. The senior primary pupils and secondary school students who are adolescents are very much influenced by this factor because at this stage in their life they feel the need for new social skills, security, recognition and acceptance by their entourage as an ingredient for their mental health (Baster, 1999; Kloonok \& Cosden, 1994; Juvonen \& Bear, 1992).

The roles that we play in our lives have an influence on our self-concept because these different roles become part of our person. Our roles determine how other people see us, which is very crucial to the adolescents. They are noted for role confusion because at one time they are expected to behave like adults and at other times they are regarded as young children. The role we assume is like a mask (Goffman, 1956), which we use over and over until it becomes incorporated into our self-concept when we become domesticated into it. Therefore it is imperative that these adolescents be tailored into the appropriate roles geared toward building in them a positive self-concept. The last factor that influences selfconcept is identification with others, which is the strife to copy what our role models are like.

\section{Self-Concept of Academic Ability}

The study of "self-concept" has awakened growing research interest in this area. But despite the profusion of studies devoted to it, it is difficult to find a unanimous, accepted definition of the term "self-concept", given that it has been approached from different theoretical perspectives. Nonetheless, there exists agreement among the different authors in that the term "self-concept" has a multidimensional nature. They agree that the term selfconcept comprises various dimensions, areas or facets, some of which are more related to certain personality aspects (physical, social, emotional), while others appear to be more linked to academic achievement in different areas and subjects (Elbaum and Vaughn, 1999; Ryan Short and Weed, 1986).

Self-concept is "the set of perceptions or reference points that the subject has about himself; the set of characteristics, attributes, qualities and defiance, capacities and limits, values and relationships that the subject knows to be descriptive of himself and which he perceives as data concerning his identity", (Hamachek, 1981, quoted by Machargo, 1992:24). This means that self-concept is the knowledge and attributes that we have about ourselves; the perceptions that we assign to ourselves and characteristics or attributes that we use to describe ourselves. It is understood to be fundamentally "a descriptive assessment and has a cognitive nuance" (Shunk, 1990).

Shevelon, Hubner and Stanton (1976) have defined the 'selfconcept' as the perceptions that each one has about himself, formed from experiences and relationships with the environment, where significant people play an important role" (p.182). Therefore, according to them, the importance of self-concept stems from its contribution to personality formation. It has to do with social competence, since it influences how a person feels, how he/she thinks, learns, values himself/herself, relates to others, and ultimately, how he/she behaves (Clark, Clemes and Bean, 2000; Clemes and Bean, 1996).

Educational psychology has been concerned with analyzing different types of relationships, both associative and predictive, that exist between self-concept and academic performance (Hay, 1997; Chapma, 1992; in Rawlingson, 1996). Self-concept of academic ability tends to be domain specific, meaning that the students have different selfconcepts towards different areas of the curriculum (Shunk, 1990). However, there is agreement in the literature reviewed, that all children are natural learners and begin life with a drive to acquire knowledge, understand it and make use of it. Children do not begin school with the intention to seek failure or frustrating their teachers (Schunk, 1990). But Everett (1991) has shown that there exist meaningful and consistent differences between the self-concept configuration of high, medium and low academic achievers. He studied the self-concept configurations using a sample of 59 female students in a Catholic residential college. The results revealed that the self-concept is positively related to achievement. Recent researchers have also shown close relationship between self-concept and academic achievement. For example, Marsh and Yeung (1996) have shown that academic effects such as whether the student looks forward to Mathematics classes, feels that Mathematics will be useful, and is afraid to ask questions in class can affect his/her performance in Mathematics. Students who 
are confident of their learning abilities, and feel a sense of self-worth, display greater interest and motivation in school, which enhances achievement. Higher achievement in turn, validates one's self-confidence for learning and maintains a high sense of self-esteem (Rawlingson, 1996). All children like to experience success, which makes them feel good about themselves, especially when they achieve a challenge which is really what they need.

Mboya (1986), on the other hand, differed with the results mentioned above when he carried out a study to determine the relationship among global self-concept, self-concept of academic ability and academic achievement of 211 black American students. Using the Pearson Product Moment Correlation and Fisher Statistics, he found that no significant relationship existed between self-concept and academic ability and academic achievement, although the relationship between self-concept of academic ability and academic achievement reached significance. He also found that the relationship between self-concept of academic ability and academic achievement correlated more strongly than the relationship between global self-concept and academic achievement.

However, the beneficial effects produced by a good level of self-concept have been sustained. For instance, in the studies by Muijs (1986) where subjects with a high self-concept were compared with other subjects, teachers' reports revealed that they considered the high self-concept students as more popular, cooperative, and persistent in class work, with lower anxiety levels, more supportive families and higher expectations of future success.

the concept of self-efficacy or one's belief about the ability to be successful in a given situation (Bandura, 1977). When barriers begin to impede progress, self-efficacy beliefs help determine how much effort will be expended in learning. In an academic arena, an individual might have low self-efficacy beliefs in a particular subject area and high self-efficacy beliefs in others.

Perceived self-efficacy is defined as people's beliefs about their capabilities to produce designated levels of performance that exercise influence over events that affect their lives. Self-efficacy beliefs determine how people feel, think, motivate themselves and behave. Such beliefs produce these diverse effects through four major processes. They include cognitive, motivational, affective and selection processes.

According to Bandura, (1986) there are four sources or influences of self-efficacy beliefs: mastery experiences, vicarious experiences, social persuasion, and physiological and emotional states. Mastery experiences are those that reinforce beliefs of competence. Successes tend to raise a person's level of self-judgment, whereas failures tend to lower it. Individuals with a strong series of successful experiences are usually able to accept an occasional failure with little or no overall effect on their positive self-efficacy beliefs. Easy successes, however, do not facilitate positive self-efficacy beliefs and should not be encouraged as a way to change self-judgments.

Vicarious experiences influence self-efficacy beliefs by offering individuals the opportunity to observe others similar to them performing well. It has been noted that observing others as they model successful behaviour can help raise a person's own self-appraisal if there is some recognition of similarity between them. The third type of influence- social persuasion- is somewhat helpful in countering a person's self-doubt, but it is not effective alone. Social persuasion involves pressure to meet the expectations of others to perform or belong. For example, participation in a group learning activity can be facilitated by others in the group seeking a common goal. In order to produce a change, social persuasion must be accompanied by other influences.

Reducing stress and negative emotions can also help combat negative self-efficacy beliefs. It is known that anxiety, frustration, and depression are all influenced by one's beliefs of competence. When learners are in supportive psychological environments, they tend to have higher selfefficacy beliefs that enable them to better handle difficult situations when they arise (Multon, Brown, and Lent, 1991).

The effects of high and low self-efficacy beliefs are significant. A strong sense of efficacy enhances human accomplishment and personal well-being in many ways. High self-efficacy beliefs result in enhanced efforts during difficult tasks, reduced stress in taxing situations, and the choice of goals that are challenging and that sustain interest and involvement. People with high assurance in their capabilities approach difficult tasks as challenges to be mastered rather than as threats to be avoided. Such an efficacious outlook fosters intrinsic interest. They set themselves challenging goals and maintain strong commitment to them. They heighten and sustain their efforts in the face of failure. They quickly recover their sense of efficacy after failures or setbacks. They attribute failure to insufficient effort or deficient knowledge and skills which are acquirable. They approach threatening situations with assurance that they can exercise control over them.

On the other hand, low self-efficacy beliefs result in reduced efforts, tendencies to give up when faced with difficult tasks, increased attention to personal deficiencies, the development of avoidance behavior, increased anxiety and stress, and the likelihood of lowered aspirations (Bandura, 1986). People who doubt their capabilities shy away from difficult tasks which they view as personal threats. They have low aspirations and weak commitment to the goals they choose to pursue. When faced with difficult tasks, they dwell on their personal deficiencies, on the obstacles they will encounter, and all kinds of adverse outcomes rather than concentrate on how to perform successfully. They slacken their efforts and give up quickly in the face of difficulties. They are slow to recover their sense of efficacy following failure or setbacks. Because they view insufficient performance as deficient aptitude it does not require much failure for them to lose faith in their capabilities.

Previous successes and failures help determine an individual's self- efficacy beliefs. When faced with repeated failures, learners may take beliefs of incompetence and integrate them with their concept of self, thus making it difficult to separate self from belief (Nisbett and Ross, 1980). Pupils with a low self esteem doubt their capabilities and shy away from difficult tasks. Because of this, they are unable to face any task they think is difficult. The end result is that their achievement is low. 


\section{METHODOLOGY}

The design deemed appropriate for this study was the survey research design. This was because; this study necessitated the collection of opinions or views from a sample, in relation to the variable under investigation. The views of pupils were collected with the use research instruments.

The target population of the study was made up of all the pupils of all the Government Primary Schools in rural areas of Fako Division. The accessible population was made up of the pupils of classes 4,5 , and 6 from three government primary schools of rural areas from each Sub-Division.

A sample of 150 pupils was used for this study. To arrive at this number, the researcher selected 30 pupils from each school in the accessible population, selecting 10 pupils from each of the accessible classes. The sampling technique used to select the pupils was the simple random sampling technique by use of the table of random numbers.

To do it, all the pupils in the accessible classes were assigned numbers running from 001 to the last name. Since it was intended that 30 pupils be drawn from each accessible school, beginning from column one on the table, we selected any figure which fell between 001 to the highest number assigned to a member of the accessible population. Once 30 numbers were selected, the corresponding pupils who were assigned to those numbers became the sample for that school.

These answered the questionnaire. From the sample of 150 pupils, two children were selected from each of the various schools in the accessible population to answer an interview. Thus 10 pupils responded to the interview Instruments for data collection were validated through face and content validity.

Both descriptive and inferential statistics were used to analyse the results. For descriptive statistics, frequencies, percentages and bar charts were used to describe the responses registered. For inferential statistics, the chisquare test of independence was used to verify the hypotheses.

The formula for percentage $(\%)$ is given by:

$$
\%=\frac{\text { Number of particular response } \times 100}{\text { Sample }}
$$

The chi-square $\left(x^{2}\right)$ formula is given by:

$$
x^{2}=\sum \frac{(O-E)^{2}}{E}
$$

Where $0=$ Observed frequencies

$\mathrm{E}=$ Expected frequencies

$\sum=$ sum of

The expected frequencies (E) are given by:

$$
E=\frac{f r \times f c}{N}
$$

Where $\mathrm{fr}=$ Total frequency of rows

$\mathrm{fc}=$ Total frequency of columns

$\mathrm{N}=$ sample size
The degree of freedom (df) is given by

$\mathrm{df}=(\mathrm{r}-1)(\mathrm{c}-1)$

Where $r=$ number of rows

$\mathrm{c}=$ number of columns

Where the chi-square calculated value is greater than the chi-square critical value, the null hypothesis is rejected and the alternative hypothesis retained. Otherwise, the null hypothesis is retained and the alternative rejected. Where the null hypothesis is rejected and the alternative retained, the magnitude of influence is determined by comparing the contingency coefficient value (c.c) to the contingency maximum value $\left(\mathrm{C}_{\max }\right)$. The values are determined by using the formulae.

$$
c . c=\sqrt{\frac{x^{2}}{x^{2}-N}}, \quad C_{\max }=\sqrt{\frac{k-1}{k}}
$$

Where $x^{2}=$ Chi-square calculated value

$\mathrm{N}=$ Sample size

$\mathrm{k}=$ Smaller number of rows and columns.

\section{FINDINGS}

An easy and a more comprehending approach was used to establish a relationship between pupils self perception and academic performance as presented on the table below

\begin{tabular}{|l|l|l|}
\hline Pupils' Self Perception & Frequency & Percentage \\
\hline
\end{tabular}

\begin{tabular}{|c|c|c|}
\hline Negative & 102 & 68.0 \\
\hline ientific Positive & 48 & 32.0 \\
\hline Total & $\mathbf{1 5 0}$ & $\mathbf{1 0 0 . 0}$ \\
\hline
\end{tabular}

When the response format and weighting scale was used to score respondents, $68 \%$ were classified to have a negative self perception, while $32.0 \%$ have a positive self perception. These results can be presented in bar charts as in figure 5 .

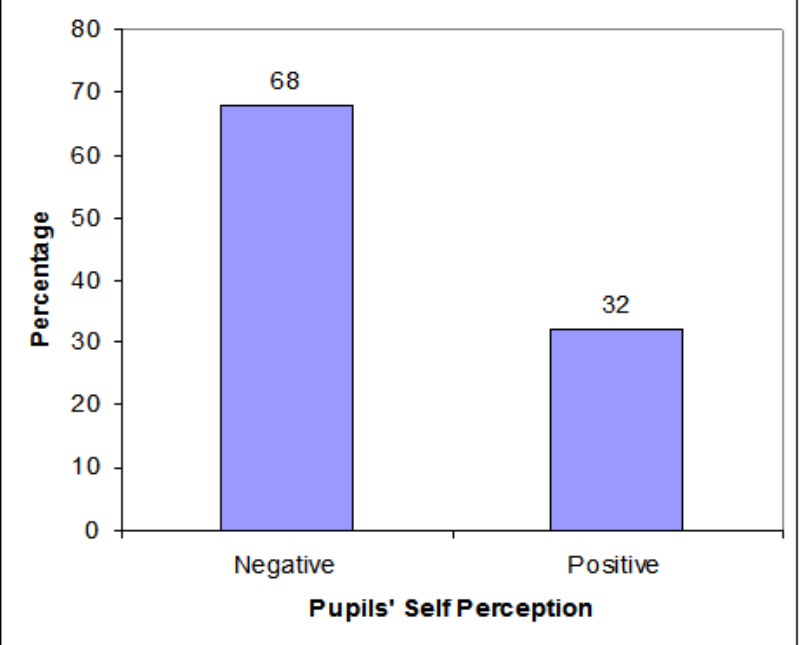

Bar-charts: Classified responses in relation to Pupils' Self perception

The taller bar is indicative of the fact that most pupils have a negative self perception.

When their interviews were analyzed, the following results were obtained 
International Journal of Trend in Scientific Research and Development (IJTSRD) @ www.ijtsrd.com eISSN: 2456-6470

\begin{tabular}{|c|l|c|c|}
\hline S.N & \multicolumn{1}{|c|}{ Responses } & Frequency & Percentage \\
\hline 1 & $\begin{array}{l}\text { I feel bad because I } \\
\text { fail in some subjects }\end{array}$ & 6 & 60.0 \\
\hline 2 & $\begin{array}{l}\text { I feel like leaving } \\
\text { school because of } \\
\text { my failure }\end{array}$ & 3 & 40.0 \\
\hline 3 & $\begin{array}{l}\text { I feel comfortable } \\
\text { although my results } \\
\text { discourage me }\end{array}$ & 2 & 20.0 \\
\hline 4 & $\begin{array}{l}\text { I feel I can make it if } \\
\text { I work harder }\end{array}$ & 2 & 20.0 \\
\hline 5 & $\begin{array}{l}\text { I am always } \\
\text { ashamed because of } \\
\text { my failure }\end{array}$ & & \\
\hline
\end{tabular}

The responses of interviewees as shown on the table above show the feelings expressed by pupils about themselves.

Presentation of Observed and Expected Frequencies
Relating Pupils' Self Perception and Underachievement
\begin{tabular}{|c|c|c|c|}
\hline $\begin{array}{c}\text { Pupils' self } \\
\text { perception }\end{array}$ & \multicolumn{2}{|c|}{ Underachievement } \\
\cline { 2 - 4 } & High & Low & Total \\
\hline Negative & $91(65.3)$ & $11(36.7)$ & 102 \\
\hline Positive & $5(30.7)$ & $43(17.3)$ & 48 \\
\hline Total & $\mathbf{9 6}$ & $\mathbf{5 4}$ & $\mathbf{1 5 0}$ \\
\hline
\end{tabular}

Figures in brackets are the expected frequencies while those without are the observed. Out of 102 pupils classified under negative self perception 91 were categorized under high underachievement, while 11 were placed under low underachievement. Out of 48 respondents classified under positive self perception, 5 were categorized under high underachievement, while 43 were categorized under low underachievement.

\section{Calculation of Chi-square Value for Hypothesis}

\begin{tabular}{|c|c|c|c|c|}
\hline $\begin{array}{c}\text { Observed } \\
\text { frequency } \\
(\mathbf{O})\end{array}$ & $\begin{array}{c}\text { Expected } \\
\text { frequency } \\
(\mathrm{E})\end{array}$ & $\mathbf{O}-\mathbf{E}$ & $(\mathbf{O}-\mathbf{E})^{2}$ & $(\mathbf{O}-\mathbf{E})^{2} / \mathbf{E}$ \\
\hline 91 & 65.3 & 25.7 & 661.5 & 10.1 \\
\hline 11 & 36.7 & -25.7 & 661.5 & 18.0 \\
\hline 5 & 30.7 & -25.7 & 661.5 & 21.5 \\
\hline 43 & 17.3 & 25.7 & 661.5 & 38.2 \\
\hline & & & & $\sum \frac{(O-E)^{2}}{E}=87.8$ \\
\hline
\end{tabular}

\section{Results}

Chi-square $\left(x^{2}\right)$ calculated value $=87.8$

Degree of freedom $=1$

Alpha level of significance $(\alpha)=0.05$

Chi-square critical value $=3.841$

\section{Interpretation of Results}

Since Chi-square calculated value (87.8) is greater than Chisquare critical value (3.841) we reject the null hypothesis following the decision rule. Inference made leads us to conclude that, there is a significant relationship between pupils' self perception and their underachievement in rural areas. The magnitude of the relationship between the two variables is determined by comparing the contingency coefficient value (c.c.) to the contingency maximum value $\left(\mathrm{C}_{\max }\right)$. These values are calculated using the formulae in chapter 3 .

$$
\text { c.c. } \sqrt{\frac{87.8}{237.8}}=0.61, \quad \mathrm{C}_{\max }=\sqrt{\frac{1}{2}}=0.71
$$

\section{Magnitude of Relationship}

\begin{tabular}{|c|c|c|}
\hline Magnitude & Range & $\mathrm{C}_{\max }$ \\
\hline $0.475-0.71$ & High & \multirow{3}{*}{0.71} \\
\cline { 1 - 2 } $0.245-0.47$ & Moderate & \\
\hline $0-0.24$ & Low & \\
\hline
\end{tabular}

Since 0.61 lies within 0.475 and 0.71 , the magnitude is high. This implies that, there is a high relationship between pupils' self perception and their underachievement in rural areas.

The results of this study showed that $68.0 \%$ of pupils in rural areas have a negative self perception, while $32.0 \%$ have a positive self perception. At the same time $64.0 \%$ of the pupils have a high underachievement, while $36.0 \%$ have a low underachievement. In other words, a majority of the pupils suffer from underachievement. Out of 102 pupils classified under negative perception, 91 were categorized under high underachievement while 11 were placed under low underachievement. Out of 48 respondents classified under positive self perception, 5 were categorized under high underachievement, while 43 had a low underachievement.

The verified hypothesis led to the conclusion that, there is a significant relationship between the self perception of pupils from rural areas and their underachievement. The magnitude of the relationship between pupils' self perception and underachievement was determined to be high. This means that, there is a high relationship between pupils' self perception and their underachievement.

Marsh (1993) found that self perception is substantially related to academic underachievement. He says that, if selfperception is so important in determining pupils' underachievement, it is vital to examine what it is and how to build it so as to enhance learning. A reflection on the results on table 1.1 shows a low percentage pass of schools in the rural areas at the First School Leaving Certificate Examination. Evaluation of the self perception of pupils from this area also showed that most of them have a negative self perception. This may be a contributory factor to their underachievement.

Patterson (1966) sees the self as a presentation of the ego, which is a combination of all that the self executes such as awareness, evaluation, regards and control of the being. A pupil with a "negative self" lacks awareness, does not carry out self evaluation, will always think that he/she is not loved, and sees himself as a defeatist in every endeavour. Such a conception does not promote hard work because; he/she believes that he/she cannot make it.

A flashback to the responses on the pupils' questionnaire, for item 5 - out of 150 respondents, 111 indicated that they are not important. For item 7, out of 150 pupils, 121 indicated that they think that, many people do not find them useful. With such a perception about the "self", it means very little can be achieved.

The results of pupils' interview also showed that $60 \%$ of pupils interviewed feel bad about themselves particularly when they fail. This means that they don't like failure but their inner man has been pushed towards it, because of the way they feel about themselves. In the same way, Aremu and Sokan (2003) submitted that, the search for the causations of poor academic achievement is unending, but prominent 
amongst such factors are self-esteem, self-efficacy, emotional problems, study habits and poor interpersonal relationships.

\section{REFERENCES}

[1] Adeyemo, D. A. (2005). Parental Involvement Interest in Schooling and School Environment as predictors of Academic Self-efficacy among fresh Secondary School Student in Oyo State, Nigeria. Electronic Journal of Research in Educational Psychology, 5-3 (1) 163-180.

[2] Alexander, P.A. \& Murphy, P.K. (1994). The Research Base for APA's Learners Centred Psychology Principles. Paper presented at the American Educational Research Association Annual Meeting, New Orleans, and L.A.

[3] Ann, C.H. \& Raleigh, N.C. (1996). Adolescents' motivation, behaviour and achievement in science. Research maths to the science teacher. No. 9603.

[4] Anunola, K.; Nurmi, J.E., Niemi, P.J., Lerkkanen, M.E., Rasku-Puttonen, H. (2004). Developmental dynamics of achievement strategies, reading performance and parental beliefs. Journal of early childhood research 2(2) 139-156.

[5] Aremu, A. 0. (2000). Academic performance 5 factor inventory. Ibadan: Stirling-Horden Publishers.

[6] Atkinson, R.L. and Atkinson, R.C., Smith, E.E., Daryl, D.J. (1990). Introduction to psychology. 10 th Edition; New York: Harcourt Brace Jovanovich.

[7] Bandura, A. (1997). Self-efficacy. The exercise of control. New York: W.H. Freeman and Company.

[8] Bandura, A., and Menlove, F.L. (1968). Factors determining vicarious extinction of avoidance behaviour through symbolic modeling. Journal of Personality and Social Psychology, 8, 99-108.

\section{Develo}

[9] Baumrind, D. 91973). The development of instrumental competence through socialization. Minneapolis: Minnesota Press.

[10] Cameroon (1998). Law No. 981/004 of April 1998 to lay down guidelines for education in Cameroon. Yaounde: Ministry of National Education. Biehler, R. \& Snowman, J. (1989). Psychology applied to teaching. (9th edition). Boston: Houghton Mifflin.

[11] Clemes, H. \& Bean, R. (2000). How to develop self-esteem in adolescents. Madrid: Editorial Debate.

[12] Cloninger S.C. (1993). Theories of personality. Understanding persons. Russel Sage College. Englewood Cliffs, New Jersey: Prentice - Hall, Inc.

[13] CRIRES, (2005). In international observatory on academic achievement (10AA), 2006.

[14] Educational Research Network for West and Central Africa (ROCARE). Université de Corody - Abidjan.

[15] Elbaum, B. and Vaughn, S. (1999). Can school-based international enhance the self-concept of students with learning disabilities? A research synthesis. National Centre for Learning Disabilities, Inc.

[16] Feldman, S.R. (1999). Understanding psychology, $5^{\text {th }}$ edition. University of Massachusetts - Amherst. McGrawHill Companies, Inc.
[17] Feldman, S.R. (2000). Essentials of understanding psychology. Fourth edition, New York: McGraw-Hill Companies, Inc.

[18] Gage, N.L. \& Berliner, D.C. (1988). Educational psychology. Boston: Houghton Mifflin.

[19] Gerow, J.R. (1997). Psychology: An introduction. $5^{\text {th }}$ Edition; New York: Addison - Wesley Educational Publishers Inc.

[20] Graham, S. (1991). A review of attribution theory in achievement contexts. Educational psychology review, 3,5-39.

[21] Haas, T. (1992). What can I become: Educational aspirations of students in rural America. Eric Digest.

[22] Havrey, J.H. \& Weary, G. (1985). Attrition: Basic issues and applications, Academic Press Diego.

[23] Hornby, A.S. (2002). Oxford learner's dictionary of current english (6 $6^{\text {th }}$ ed.). Oxford University Press, UK.

[24] http://www.thefreelibrary.com/Factors+related+to+the +underachievement+of+university+students+in...a0150850210

[25] http://www.eurojournals.com/ejss_13_2_08.pdf

[26] Jay, W.C. (2005). Achievement and success: Built with the power. Watch Newsletter. New York.

[27] Jorenyin, M.A. and Monday, J.J. (2004). Self-concept, attitude and achievement of secondary school students in science in Southern Cross River State, Nigeria. The African Symposium Vol. 4, No. 1.

[28] Journal Pajares, F. (1996). Self-efficacy beliefs in academic settings. Review of Educational Research, 66, 533-578.

[29] Liyod J. \& Weiton C. (2000). Psychology applied to modern life. $6^{\text {th }}$ Edition. New York: McGraw-Hill Companies Inc.

[30] Lowell E. Madden "Motivating students to learn better through own goal-setting". Education. FindArticles.com. $28 \quad$ Oct, 2010. http://findarticles.com/p/articles/mi_qa3673/is_n3_v1 17/ai_n28686506/

COPYRIGHT 1997 Project Innovation (Alabama) COPYRIGHT 2008 Gale, Cengage Learning

[31] Machargo, J. (1992). The teacher and self-concept in his or her students. Theory and practice. Madrid Escuela Espaniola.

[32] Marsh, H.W. \& Yeung, A.S. (1993). Causal effects of academic self-concept on academic models of longitudinal data. British Journal of Educational psychology, (Vol. 89), 41-54.

[33] Marsh, H.W., \& Yeung, A.S. (1996). The distinctiveness of affect in specific school subjects: An application of confirmatory factor analysis with the national longitudinal study of 1988. American Educational Research Journal, 67, 665-680.

[34] Mboya, M.M. (1986). Black adolescents: A descriptive study of their self-concepts and academic achievement. Adoelscent, 21 (83); 689-96.

[35] Mboya, M.M. (1998). The concept of attitude in social psychology. Journal of Psychology, 19, 329-39. 
[36] Nicholls, J.G. (1984). Conceptions of ability and achievement motivation. In R. Ames and C. Ames (Eds.), Research on Motivation in Education (Vol. 1). New York: Academic Press.

[37] Nsamenang, A.B. (1980). Locus of control as correlate of academic achievement and educational aspirations. (unpublished M.Ed dissertation, University of Ibadon, Nigeria, 1980).

[38] Papalia, E.D. \& Olds, W.S. (1992). Human development. $5^{\text {th }}$ ed., New York: McGraw-Hill Companies Inc.

[39] Piaget, J. (1970). Science of education and the psychology of the child. New York: Vikings Press.

[40] Piaget, J. 91974). To understand is to invent. New York: Viking Press.

[41] Ramdom House Unabridged Dictionary (1997). Random House, Inc.

[42] Rawlingson, C. (1996). Self-concept, self-efficacy, and programmed enrichment. In D. M.C.Alpine and R. Moltzen (eds.), Gifted and talented: New Zealand perspective. Palmerson North: ERDC press Cheire, Mt. Kraut, R.E. (1979). Increasing educational achievement via self-concept change. Review of educational research. Vol. 49, 131-150.

[43] ROCARE No. 1, (2010).

[44] Rogers, R.C. (1961). On becoming a person. A therapist's view on psychology. (Sentry ed.). Houghton Mufflin Co., Boston.

[45] Santrock, W.J. (2001). Educational psychology. New York: McGraw-Hill Companies Inc.

[46] Saul Kassin (2001). Psychology. Williams College. Prentice Hall. Upper Saddle River. New Jersey.

[47] Schunk, D.H. (1990). Self-concept and school achievement. In C. Roger and P. Kutrick (eds.). The social psychology of the primary school. London: Rout ledge.

[48] Schunk, D. (1984). "Enhancing self-efficacy and achievement through rewards and goals: Motivational and informational effects." Journal of Educational Research 78, 29-34.

[49] Silverman, Sharon L., Casazza M.E. (2000). Making connections to enhance teaching. First Edition. JosseyBass Publishers: San Francisco.

[50] Spence, J.T. (1983). Achievement and achievement motives: Psychological and sociological approaches. San Francisco: Freeman.

[51] Sprinthall N.A. and Sprinthall R.C. (1990). Educational psychology. A development approach. $5^{\text {th }}$ Edition. New York: McGraw-Hill Inc.

[52] Stipek, d.J. (1993). Motivation to learn: From theory to practice. (2nd edition). Boston: Allyn and Bacon.

[53] Sunberg M.D. (1997). Assessment of persons. New Jersey: Prentice-Hall Inc

[54] Tambo, L.I. (2003). Principles and methods of teaching: Application in Cameroon schools. Limbe: Anucam Publishers.

[55] Tchombe, T.M. (2004). Psychological parameters in teaching. Yaounde Presses Universitaire d'Afrique.

[56] Trowbridge, L.W. and Bybee R.W. (1986). Becoming a secondary school science teacher. (4th ed.). Merrill Publisher Company. A Bell \& Howell Company, London.

[57] Vasta R., Haith M.M., Miller A.S. (1992). Child psychology. The modern science. New York: Permission. Department, John Wiley and Sons.

[58] Wallace, S.R. \& Thompson, T.E. (1995). Pre-service teachers' changing attributions for elementary students success or failure. Paper presented at the annual meeting of the Mid-West Educational Research Association Chicago, IL.

[59] Weiner, B. (1986). An attribution theory of motivation and emotion. New York: Springer - Verlag.

[60] Wool folk, A.E. (1990). Educational psychology. London: Englewood Cliff. 